\title{
Age and Growth of the Elongate Ilisha Ilisha elongata
}

\author{
Jin Koo Kim*, Ok In Choi ${ }^{1}$, Joo Il Kim², Dae Soo Chang \\ and Kyeong Dong Park
}

\author{
Fisheries Resources Research Team, National Fisheries Research and Development Institute, 408-1, \\ Sirang-ri, Gijang-up, Gijang-gun, Busan, 619-902, Korea \\ ${ }^{1}$ Tidal-flat Research Center, West Sea Fisheries Research Institute, National Fisheries Research and \\ Development Institute, Gunsan, 573-882, Korea \\ ${ }^{2}$ Fisheries Resources Team, South Sea Fisheries Research Institute, National Fisheries Research and \\ Development Institute, Yosu, 556-823, Korea \\ ${ }^{3}$ Department of Marine Biology, Pukyong National University, Busan 608-737, Korea
}

\begin{abstract}
We present age and growth data for Ilisha elongata, based on 363 specimens caught in 1999 and 2000 around Jeju Island and the southwest coast of Korea. Scale and ring radii of each ring group showed a direct one-to-one relationship, with ring radius increasing as scale radius increased. The relationship between fork length and scale radius was $F L=39.553 \mathrm{SR}+60.935$ for females, $\mathrm{FL}=39.474 \mathrm{SR}+54.026$ for males, and $\mathrm{FL}=39.608 \mathrm{SR}+57.547$ for both sexes. Monthly changes in the marginal index indicated that a new ring appears once each year (in July). Maximum age, mean age and mean fork length of fish were 10 years, 5.0 years, and $349 \mathrm{~mm}$, respectively. Von Bertalanffy's growth equations were $\mathrm{FL}_{\mathrm{t}}=495.4 \times[1-\exp (-0.2586(\mathrm{t}+0.6487))]$ for fork length $(\mathrm{mm})$ and $\mathrm{W}_{\mathrm{t}}=1,112.5 \times[1-\exp (-0.2586(\mathrm{t}+0.6487))]^{2.874}$ for body weight $(\mathrm{g})$ for both sexes. Monthly changes in the gonadosomatic index (GSI) indicated that the spawning period was in June and July, which corresponded closely with ring formation time. Differences in monthly GSI changes in 1999 and 2000 may be related to water temperature variation. Fecundity ranged from 5,664 to 176,290 eggs per individual $(\mathrm{n}=43$, fork length $264-470 \mathrm{~mm}$ ). The relationship between fecundity (F) and fork length was $\mathrm{F}=7.7 \times 10^{-7} \times \mathrm{FL}^{4.9269}$.
\end{abstract}

Key words: Ilisha elongata, Elongate ilisha, Age, Growth, Maturity, Scale

\section{Introduction}

The elongate ilisha Ilisha elongata is a common migratory fish species in coastal Korea, Japan, and the East China Sea (Whitehead, 1985; Nelson, 2006; Youn and Kim, 1998; Nakabo, 2002). The species has also been recorded in the Indian Ocean (Kuwait Bay and Pondicherry), Java Sea (Singapore) and South China Sea (Sarawak), in addition to the East China Sea (from Canton north to Korea and off southern Japan, north to Osaka on the Pacific coast and Fukuoka, Japan) and Peter the Great Bay (Blaber et al., 1998; Froese and Pauly, 2006).

In Korea, the elongate ilisha overwinters off the coast of southwest Jeju Island and spawns in river mouths before migrating southward (Kim et al., 1994). Although it is a marine species, it occupies

\footnotetext{
*Corresponding author: taengko@hanmail.net
}

both pelagic and inshore habitats, and it is presumably able to tolerate lower salinity, as it enters estuaries in the spawning season (Whitehead, 1985; Yamada et al., 1986). Recently, biology of six species of Ilisha was investigated in estuaries in Sarawak, providing some information on their reproduction, diet, age, and growth (Blaber et al., 1998). In the East China Sea, three populations of elongate ilisha, distinguishable by their migration routes, were reported by Yamada et al. (1986). Subsequently, this species has been little studied.

Elongate ilisha is a commercially important species (Froese and Pauly, 2006); the harvest in Korea peaked at 5,067 $\mathrm{t}$ in 1982. A drastic decline in catches since 1991 (NFRDI, 2005) has prompted a call for research of the fish stock. Although aspects of the systematics (Whitehead, 1985; Youn and Kim, 1998), fisheries (Yamada et al., 1986; Blaber et al., 1998), 
diet, age, and growth (Blaber et al., 1998), distribution (Whitehead, 1985; Blaber et al., 1998), and occurrence of larvae and juveniles (Han et al., 2000; Kim et al., 2003) have been studied, there has been little research on aging, growth, and maturity of elongate ilisha from waters adjacent to Korea, which is a necessary prerequisite for a sound management program.

The objectives of this study were to estimate age, growth, and maturity of elongate ilisha off Jeju Island and the southwest coast of the Korean peninsula.

\section{Materials and Methods}

We examined 363 elongate ilisha that were caught off the southwest coast, Jeju-do and Ieo-do (=Socotra) of Korea from January to December 1999 and from May to July 2000 (Fig. 1, Table 1).

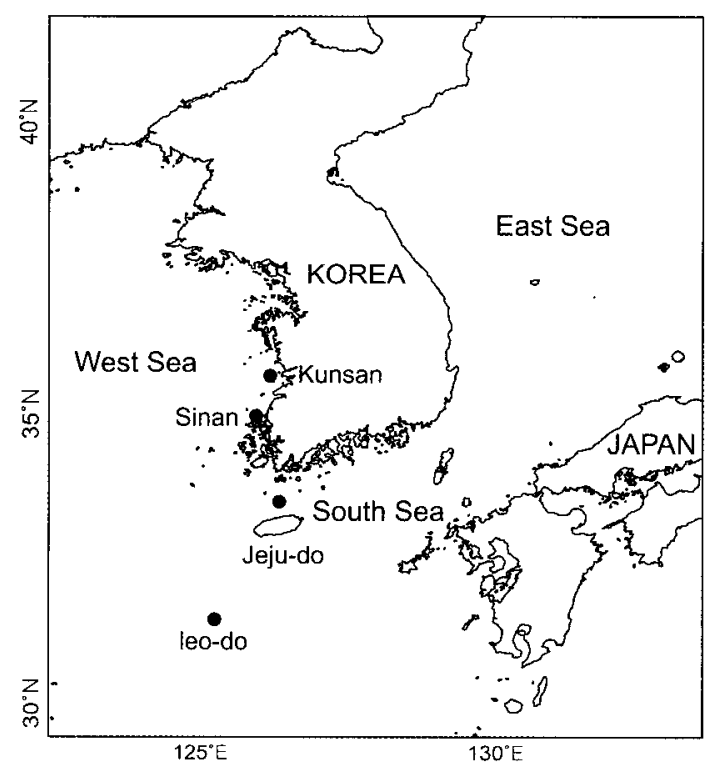

Fig. 1. Study area. Solid circles indicate the sampling sites.

To assess age, 3-4 scales from inside the pectoral fin were examined (Fig. 2). To estimate ring formation time, 292 scales were analyzed with an image analysis equipment (Image-Pro Plus, Version 4.5) to measure ring and scale radii. The marginal index (MI) was calculated as follows:

$$
M I=\left(R-r_{n}\right) /\left(r_{n}-r_{n-1}\right)
$$

where $R$ is scale radius, $r_{n}$ is ring radius from the most exterior point, and $r_{n-1}$ is the first ring radius from the most exterior ring.

Body weight was measured to the nearest $0.1 \mathrm{~g}$ and fork length to the nearest $0.1 \mathrm{~mm}$ with a Vernier
Table 1. Sampling data for Ilisha elongata collected from waters adjacent to Korea

\begin{tabular}{lclc}
\hline Year/Month & $\begin{array}{c}\text { Number of } \\
\text { specimens }\end{array}$ & Fishing area & $\begin{array}{c}\text { Fork length } \\
(\mathrm{mm})\end{array}$ \\
\hline 1999 January & 34 & Jeju strait & $334-480$ \\
Feburary & 20 & Jeju strait & $420-467$ \\
March & 19 & Jeju strait & $407-504$ \\
April & 24 & Jeju strait & $342-434$ \\
May & 16 & Jeju strait & $360-468$ \\
June & 37 & Sinan & $278-470$ \\
July & 36 & Sinan & $230-398$ \\
August & 11 & Kunsan & $187-237$ \\
September & 22 & Sinan & $195-240$ \\
October & 30 & leo-do & $340-421$ \\
November & 35 & Jeju strait & $290-432$ \\
December & 24 & Jeju strait & $305-453$ \\
2000 May & 31 & Sinan & $236-310$ \\
June & 17 & Sinan & $291-549$ \\
July & 7 & Sinan & $305-380$ \\
\hline
\end{tabular}

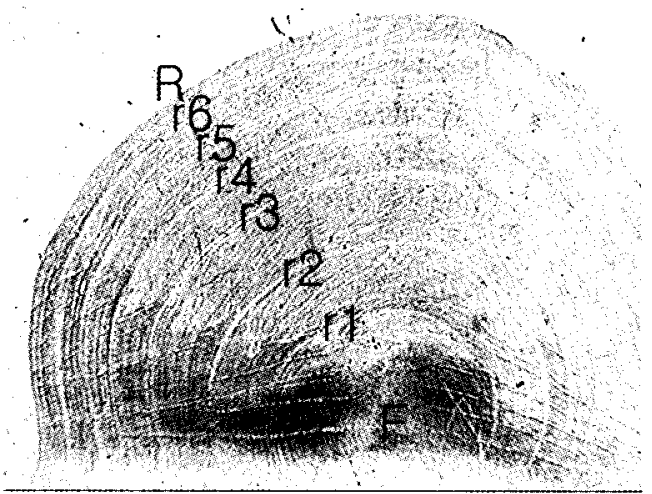

Fig. 2. Scale diagram for age determination of Ilisha elongata. $\mathrm{F}$ indicates the focus, $\mathrm{r} 1-\mathrm{r} 6$ are the first to sixth rings. $\mathrm{R}$ is the exterior margin.

caliper. To estimate the gonadosomatic index (GSI), the gonad weight was divided by the body weight and multiplied by $10^{3}$.

The interconnectivity between scale and ring radii of each ring group was examined to determine the relationship between the rings. The range of $r_{1}-r_{n}$ between the ring groups was subjected to the RyanEinot-Gabriel-Welsch Multiple Range test (SAS, Version 6.12) in order to clarify if abnormal rings were present. Lee's phenomenon was investigated based on the interconnectivity between the ring radius of each ring group and then revised as follows: the intersection of the linear regression line for the same ring radius of each group and the $\mathrm{Y}$-axis of the corresponding age was taken as the estimated ring radius at the time of ring formation. The estimated ring radius was then substituted into the linear regression equation, since the combination of fork length and scale radius should indicate estimated fork 
length by age. The formula predicting the rate of increase in fork length was obtained from fork length increase with age dating from von Bertalanffy's growth formula (von Bertalanffy, 1938). The two largest specimens were excluded from this estimation, because they exhibited strong Lee's phenomenon. In addition, specimens between the ages of 10 and 13 years were not available.

$$
\mathrm{FL}_{\mathrm{t}}=\mathrm{FL}_{\infty} \cdot\left[1-\exp \left(-\mathrm{K}\left(\mathrm{t}-\mathrm{t}_{0}\right)\right)\right]
$$

where $F L_{t}$ is fork length at age $t, F L_{\infty}$ is the asymptotic fork length, $\mathrm{K}$ is the growth coefficient, and $t_{0}$ is the hypothetical age when the fork length is zero.

The non-linear regression equation (by sex) enabled determination of the relationship between fork length and body weight for each sex. These were log-transformed to confirm whether physical features could be associated with a particular sex and then subjected to analysis of covariance (ANCOVA; SAS, Version 6.12).

\section{Results}

\section{Age validity and ring formation time}

The scale and ring radii of each ring group showed a direct one-to-one relationship (Fig. 3), such that ring radius grew in proportion to scale radius. However, from the age of 3 years, some radii had a one-totwo relationship. Analysis of variance (ANOVA) demonstrated that the emergence of some redundant rings was non-significant. However, some elongate ilisha had redundant rings (7- and 8-year-old females; 8- and 9-year-old males).

Analysis of ring radius change over time showed that ring radii in 1-8-year-old females progressively decreased with time. In contrast, the first two ring radii in males diminished with age, indicating that the growth patterns varied with sex.

Lee's phenomenon was revised for females of $r_{1}-r_{6}$ and males of $r_{1}-r_{2}$ to reduce the error range of fork length back-calculations, owing to the diminishing average size of ring radii. Prior to revision, the average ring radius (distance between the scale focus and annual ring) was $r_{1}=2.73-$ and $r_{8}=9.77 \mathrm{~mm}$ for females and $r_{1}=2.70-$ and $r_{9}=10.19 \mathrm{~mm}$ for males. After revision, average ring radii were $r_{1}=2.87$ and $r_{8}=9.77 \mathrm{~mm}$ for females and $r_{1}=2.79$ and $r_{9}=10.19$ $\mathrm{mm}$ for males (Table 2).

Monthly fluctuations in MI, a factor for estimating the time of ring development, showed that a new scale ring appeared once a year (in July). Elongate ilisha with a low MI value in October were caught in

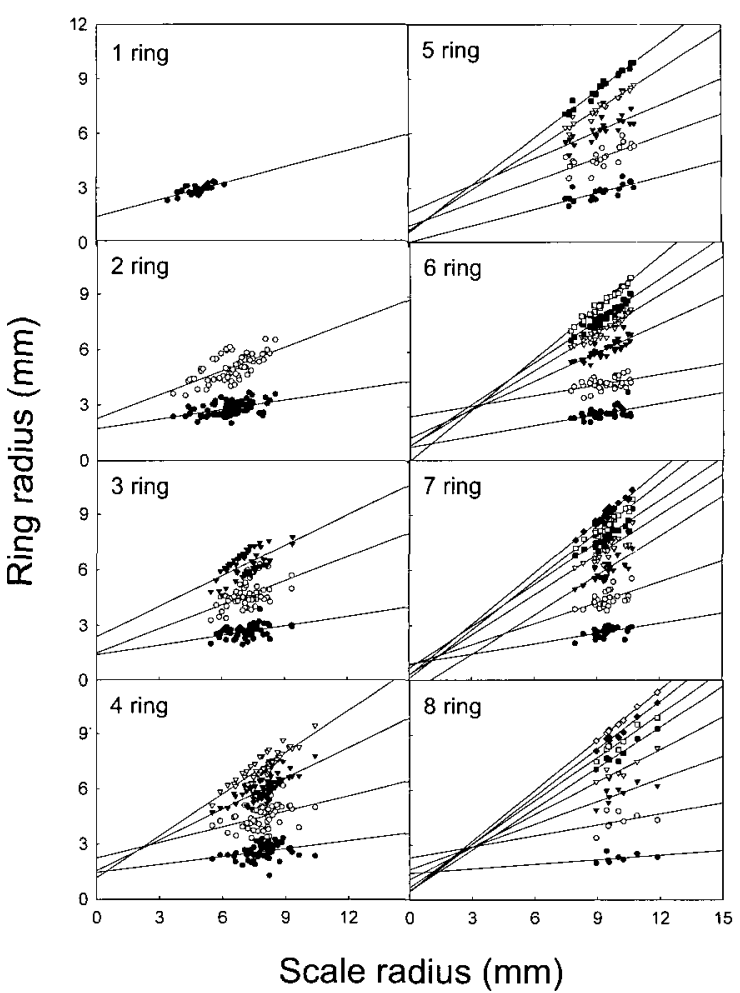

Fig, 3. Relationship between scale and ring radii of Ilisha elongata.

the Ieo-do in the East China Sea (Fig. 4).

\section{Maturity and fecundity}

The GSI in 1999 was less than 2.0 until May, then increased sharply and peaked in June (11.0), decreased slightly in July (10.1), and then decreased rapidly in August (0.3). In 2000, however, the mean GSI was higher in July than in June (Fig. 5). Estimated fecundity $(\mathrm{F})$ during the spawning period ranged from 5,664 to 176,290 eggs $(n=43,26-47 \mathrm{~cm}$ in fork length), and tended to increase with size. There was a statistically significant non-linear relationship between fecundity and fork length, $F=$ $7.7 \times 10^{-7} \times \mathrm{FL}^{4.9269}\left(\mathrm{r}^{2}=0.7, \mathrm{P}<0.01\right.$; Fig. 6).

The average sex ratio (females : males) was $1.36: 1$, with females outnumbering males except in April, August, and September.

\section{Growth}

The relationship between fork length and body weight was $\mathrm{BW}=3 \times 10^{-5} \times \mathrm{FL}^{2.8456}\left(r^{2}=0.97\right)$ for females, $\mathrm{BW}=2 \times 10^{-5} \times \mathrm{FL}^{2.9025}\left(r^{2}=0.97\right)$ for males, and $\mathrm{BW}=2 \times 10^{-5} \times \mathrm{FL}^{2.874}\left(r^{2}=0.97\right)$ for both sexes. There was no difference in relative growth between sexes (ANCOVA, $\mathrm{P}>0.05$ ).

The relationship between fork length and scale 
Table 2. Mean and estimated ring radii after correction of Lee's phenomenon for each ring group of Ilisha elongata

Females

\begin{tabular}{|c|c|c|c|c|c|c|c|c|c|c|}
\hline Ring group & $\begin{array}{l}\text { Number of } \\
\text { specimens }\end{array}$ & $\mathrm{R}$ & $r_{1}$ & $\mathrm{r}_{2}$ & $r_{3}$ & $r_{4}$ & $r_{5}$ & $r_{6}$ & $r_{7}$ & $r_{8}$ \\
\hline 1 & 12 & 4.95 & 2.90 & & & & & & & \\
\hline 2 & 50 & 6.50 & 2.86 & 5.10 & & & & & & \\
\hline 3 & 38 & 7.22 & 2.65 & 4.62 & 6.35 & & & & & \\
\hline 4 & 31 & 8.22 & 2.65 & 4.47 & 6.11 & 7.42 & & & & \\
\hline 5 & 11 & 9.82 & 2.93 & 4.92 & 6.46 & 7.89 & 9.04 & & & \\
\hline 6 & 18 & 9.40 & 2.62 & 4.18 & 6.15 & 7.35 & 8.06 & 8.85 & & \\
\hline 7 & 11 & 9.37 & 2.63 & 4.33 & 5.90 & 7.12 & 7.90 & 8.48 & 9.08 & \\
\hline 8 & 4 & 10.1 & 2.18 & 4.01 & 5.58 & 7.07 & 8.65 & 8.63 & 9.26 & 9.77 \\
\hline Mean & 175 & 7.63 & 2.73 & 4.67 & 6.19 & 7.41 & 8.27 & 8.70 & 9.13 & 9.77 \\
\hline \multicolumn{2}{|c|}{ Estimated ring radius } & & 2.87 & 4.96 & 6.35 & 7.55 & 8.72 & 8.81 & 9.13 & 9.77 \\
\hline
\end{tabular}

Males

\begin{tabular}{|c|c|c|c|c|c|c|c|c|c|c|c|}
\hline $\begin{array}{l}\text { Ring } \\
\text { Group }\end{array}$ & $\begin{array}{l}\text { Number of } \\
\text { specimens }\end{array}$ & $\mathrm{R}$ & $r_{1}$ & $r_{2}$ & $r_{3}$ & $r_{4}$ & $r_{5}$ & $r_{6}$ & $r_{7}$ & $r_{8}$ & $r_{9}$ \\
\hline 1 & 17 & 4.78 & 2.89 & & & & & & & & \\
\hline 2 & 19 & 5.89 & 2.65 & 4.69 & & & & & & & \\
\hline 3 & 15 & 7.19 & 2.71 & 4.70 & 6.29 & & & & & & \\
\hline 4 & 23 & 7.70 & 2.69 & 4.59 & 5.88 & 6.96 & & & & & \\
\hline 5 & 9 & 8.54 & 2.63 & 4.51 & 5.88 & 6.93 & 7.93 & & & & \\
\hline 6 & 13 & 9.11 & 2.72 & 4.39 & 6.11 & 7.14 & 7.78 & 8.51 & & & \\
\hline 7 & 14 & 9.54 & 2.67 & 4.49 & 6.19 & 7.23 & 7.89 & 8.52 & 9.08 & & \\
\hline 8 & 4 & 9.97 & 2.41 & 4.59 & 6.04 & 7.06 & 7.95 & 8.61 & 9.11 & 9.65 & \\
\hline 9 & 2 & 10.6 & 2.48 & 4.42 & 6.14 & 7.01 & 7.94 & 8.62 & 9.13 & 9.72 & 10.2 \\
\hline Mean & 116 & 7.48 & 2.70 & 4.58 & 6.06 & 7.06 & 7.87 & 8.53 & 9.09 & 9.68 & 10.2 \\
\hline \multicolumn{2}{|c|}{ Estimated ring radius } & & 2.79 & 4.68 & 6.06 & 7.06 & 7.87 & 8.53 & 9.09 & 9.68 & 10.2 \\
\hline
\end{tabular}

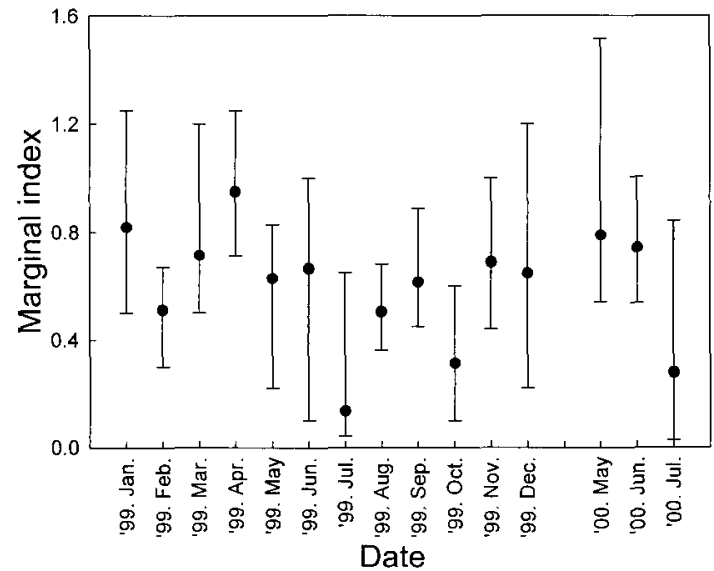

Fig. 4. Monthly changes in mean marginal index of Ilisha elongata. Error bars show the minimum and maximum values.

radius was $\mathrm{FL}=39.553 \mathrm{SR}+60.935\left(r^{2}=0.81\right)$ for females, $\mathrm{FL}=39.474 \mathrm{SR}+54.026\left(r^{2}=0.87\right)$ for males, and $\mathrm{FL}=39.608 \mathrm{SR}+57.547\left(r^{2}=0.83\right)$ for both sexes (Fig. 7). There was no significant difference between

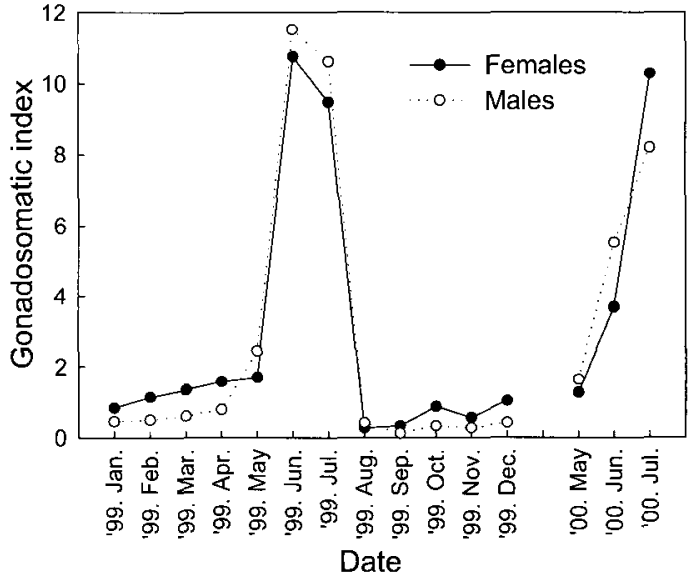

Fig. 5. Monthly changes in mean gonadosomatic index of Ilisha elongata.

sexes in the relationship of FL to SR (ANCOVA, P > 0.05 ). Accordingly, the back-calculated fork length at the time of ring formation was derived from the correlation between fork length and scale radius. Growth parameters were determined by von Ber- 


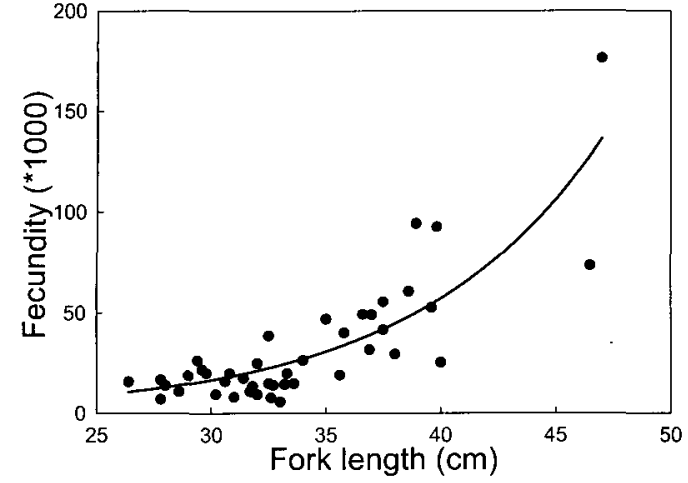

Fig. 6. Relationship between fork length and fecunddity of Ilisha elongata.

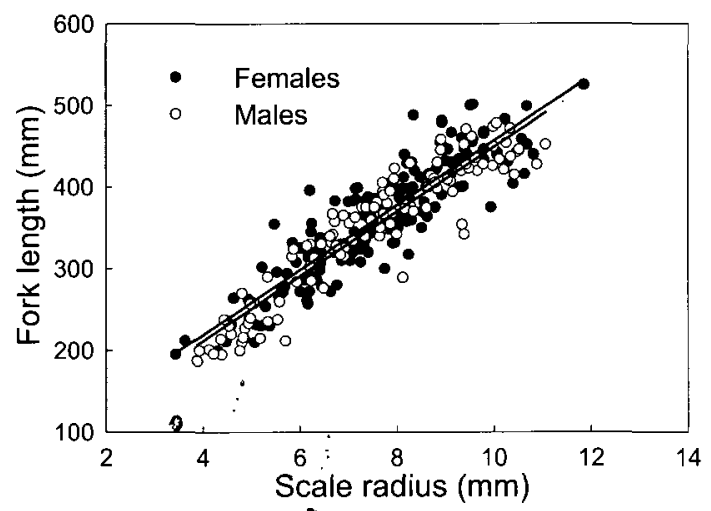

Fig. 7. Relationship between scale radius and fork length of Ilisha elongata.

talanffy's growth formula for the age-length key using non-linear regression (Table 3).

Von Bertalanffy's growth formula was $\mathrm{FL}_{\mathrm{t}}=477.6 \times$ $[1-\exp (-0.3161(\mathrm{t}+0.4357))]$ for females, $\mathrm{FL}_{\mathrm{t}}=511.7 \times$ $[1-\exp (-0.2159(\mathrm{t}+0.8449))]$ for males, and $\mathrm{FL}_{\mathrm{t}}=495.4$ $\times[1-\exp (-0.2586(\mathrm{t}+0.6487))]$ for both sexes (Fig. 8).

The growth equation for body weight based on the correlation between fork length and body weight was $\mathrm{W}_{\mathrm{t}}=1112.5 \times[1-\exp (-0.2586(\mathrm{t}+0.6487))]^{2.874}$ for both sexes (Fig. 9).

\section{Discussion}

When determining fish age, abnormal scale rings resulting from changing environmental conditions (Kim, 1989) can be mistaken for annual rings. In elongate ilisha, Lee's phenomenon causes an overlap in the relationship between scale and ring radii, with females being more affected than males. Lee's phenomenon is more likely to occur in young, fastgrowing fish and may be aggravated during harvesting (Kim, 1983).

The growth model of elongate ilisha showed that

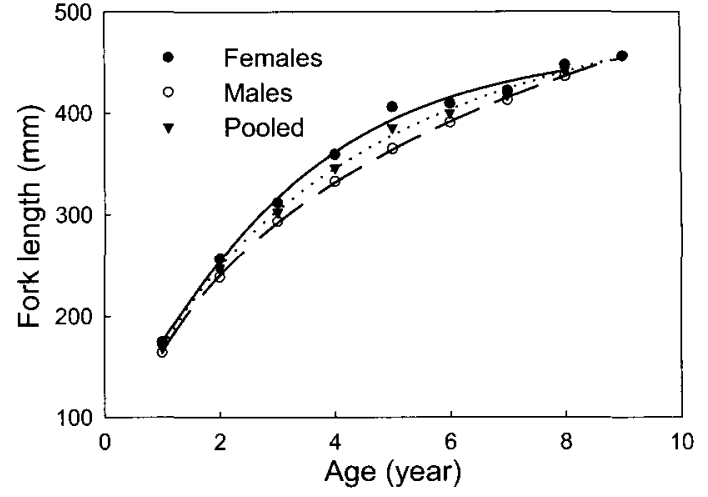

Fig. 8, Von Bertalanffy's growth curve for fork length of Ilisha elongata.

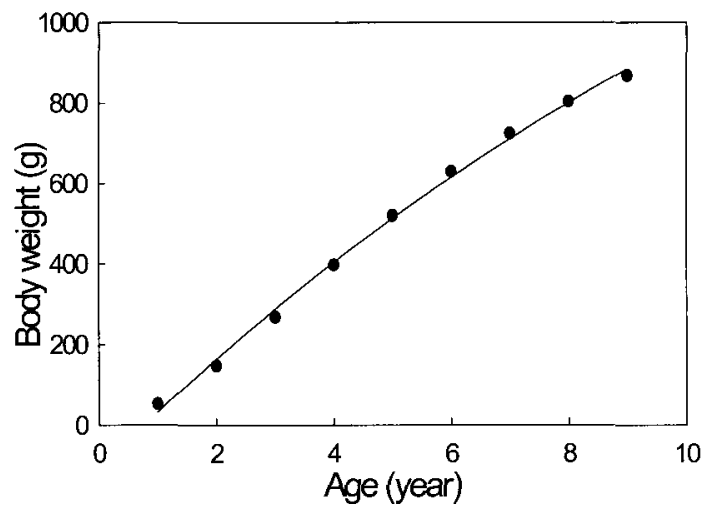

Fig. 9. Von Bertalanffy's growth curve for body weight of Ilisha elongata.

Table 3. Von Bertalanffy's growth parameters for Ilisha elongata

\begin{tabular}{cccc}
\hline Parameters & Females & Males & Both sexes \\
\hline $\mathrm{FL}_{\infty}(\mathrm{mm})$ & 477.6 & 511.7 & 495.4 \\
$\mathrm{~K}\left(\mathrm{year}^{-1}\right)$ & 0.3161 & 0.2159 & 0.2586 \\
$\mathrm{~T}_{0}$ & -0.436 & -0.845 & -0.649 \\
\hline $\mathrm{SSQ}$ & 365.6 & 132.4 & 193.6 \\
\hline
\end{tabular}

females were generally larger, with a higher growth coefficient $(0.3161 /$ year $)$ than males $(0.2159 /$ year $)$, although males had a higher asymptotic fork length $(511.7 \mathrm{~mm})$ than females $(477.6 \mathrm{~mm})$. Contrary to these results, elongate ilisha from Sarawak estuaries showed very rapid growth and a short life span (maximum age of about 3 years; Blaber et al., 1998). This may be the result of warmer water temperature and abundant prey. In fact, many small juveniles in Sarawak estuaries, particularly Clupeiformes, have higher lipid content than crustacean zooplankton (Blaber et al., 1998). In Korea, an age and growth study of Konosirus punctatus (Clupeidae) showed that maximum age was 5 years, asymptotic fork length was $25.9-27.5 \mathrm{~cm}$, and growth coefficient was 
$0.255-0.271 /$ year (Oh et al., 2000), comparable to our findings for elongate ilisha. Additionally, age and growth studies of Priacanthus macracanthus and Sillago japonica indicated that growth is faster in tropical areas than in temperate areas (Oki and Tabeta, 1999; Sulistiono et al., 1999).

As average growth at the population level represents the growth of each individual fish, there always exists the possibility that there are fish with a greater fork length than the asymptotic fork length (Kim, 1993). In elongate ilisha, the largest female caught (in June 2000) measured $549 \mathrm{~mm}$ and was 14 years old, whereas the largest male caught (in March 1999) measured $504 \mathrm{~mm}$ was also 14 years old. The two specimens were excluded from the analyses because they showed strong Lee's phenomenon. Based on the remaining specimens, the mean fork length by age, calculated from von Bertalanffy's equation, was: 1 year $=171.5 \mathrm{~mm}, 2$ years $=245.3 \mathrm{~mm}$, 3 years $=302.3 \mathrm{~mm}, 4$ years $=346.3 \mathrm{~mm}, 5$ years $=$ $380.3 \mathrm{~mm}, 6$ years $=406.5 \mathrm{~mm}, 7$ years $=426.8 \mathrm{~mm}, 8$ years $=442.4 \mathrm{~mm}, 9$ years $=454.5 \mathrm{~mm}$.

Spawning populations of elongate ilisha can be divided into two groups, one of which was confirmed by this study, and by Kim et al. (2003), who found elongata ilisha larvae (4.2-9.9 $\mathrm{mm}$ TL) off Imja Island $\left(35^{\circ} 05^{\prime} \mathrm{N}, 126^{\circ} 10^{\prime} \mathrm{E}\right)$, Korea, in June 2001 . A second group was suggested by Han et al. (2000), who recorded larvae and juveniles at Yosu, at the central southern coast of Korea. It is likely that following an overwintering period off Jeju Island, elongate ilisha migrates northward in one of two directions, one sub-population moving to western Korean (=Hwanghae) and the other to the southern coast, as water temperatures increase.

Spawning period of elongate ilisha is between April and July in both the East China Sea (Yamada et al., 1986) and off Korea (NFRDI, 2005). We found that spawning occurred between June and July off the southwest coast of Korea. The difference in monthly changes of GSI in 1999 and 2000 may reflect water temperature variation in the spawning grounds. Young fishes that are normally transported from Jeju Island were not observed when the tidal front originated from the Hwanghae cold water upwelling that occurred near Wando in 2000 (Kim et al., 2002).

Elongate ilisha with a slightly lower MI were caught in October in the Ieo-do (East China Sea), indicating that they may represent a different population from those caught off the coast of the Korean peninsula. Elongate ilisha can be separated into Korean and East China Sea populations based on their migration routes (Yamada et al., 1986; Kim et al., 2001), and Kim et al. (2001) noted that significant population differences in spawning seasons and the fork length to body height relationship. However, further research, including DNA analysis, is necessary for a complete understanding of elongate ilisha stocks off Korea.

\section{Acknowledgments}

We are grateful for the assistance provided by S.S. Kim (NFRDI) and J.H. Na (PKNU). We also thank Y.H. Kim (NFRDI) and G.S. Hardy (Whangarei, New Zealand), who reviewed the manuscript. This study was supported by National Fisheries Research and Development Institute (NFRDI).

\section{References}

Blaber, S.J.M., J. Staunton-Smith, D.A. Milton, G. Fry, T.V. Velde, J. Pang, P. Wong and O. Boon-Teck. 1998. The biology and life-history strategies of Ilisha (Teleostei: Pristigasteridae) in the coastal waters and estuaries of Sarawak. Estuar. Coast. Shelf Sci., 47, 499-511.

Froese, R. and D. Pauly. 2006. FishBase. www.fishbase. org.

Han, K.H., D.Y. Kim, B.Y. Noh, S.H. Oh, Y.M. Kim, D.S. Jin and Y.U. Kim. 2000. Morphological and skeletal development of the larvae and juveniles of the slender, Ilisha elongata (Bennett) (Teleostei: Clupeidae). Kor. J. Ichthyol., 12, 230-235.

Kim, J.K., J.I. Choi, D.S. Chang, J.T. Na and Y.U. Kim. 2003. Distribution of fish eggs, larvae and juveniles around the Youngsan River estuary. J. Kor. Fish. Soc., 36, 486-494.

Kim, J.K., J.I. Choi, D.S. Chang and I.I. Kim. 2002. Fluctuation of bag-net catches off Wando, Korea and the effect of sea water temperature. J. Kor. Fish. Soc., $35,497-503$.

Kim, J.K., O.I. Choi, J.I. Kim and D.S. Chang. 2001. Age and growth of Ilisha elongata. Abstract. Natl. Fish. Res. Dev. Inst., 77-78.

Kim, S.S. 1983. A theoretical study on the causes of Lee's phenomenon based on the scales of walleye pollocik, Theragra chalcogramma (Pallas). Bull. Fish. Res. Dev. Agency, 31, 33-48.

Kim, Y.S. 1993. Fisheries Population Dynamics. Sinheung, Pusan, 1-258.

Kim, Y.U. 1989. Introduction to Ichthyology. Taehwa, Pusan, 1-270.

Kim, Y.U., Y.M. Kim and Y.S. Kim. 1994. Commercial Fishes of the Coastal and Offshore Waters in Korea. Yemun, Pusan, 1-299.

Nakabo, T. 2002. Fishes of Japan with pictorial keys to the species, English ed. Tokai Univ. Press, Tokyo, 1-1749. 
NFRDI (National Fisheries Research and Development Institute). 2005. Ecology and Fishing Ground. Yemun, Pusan, 1-383.

Nelson, J.S. 2006. Fishes of the World (4th ed). John Wiley \& Sons, New York, 1-601.

Oh, T.Y., J.I. Kim, B.Y. Cha and J.R. Koh. 2000. Age and growth of gizzard-shad, Konosirus punctatus in the South Sea of Korea. Bull. Fish. Res. Dev. Inst., 58, 10-15.

Oki, D. and O. Tabeta. 1999. Age and growth of big eye Priacanthus macracanthus in the East China Sea. Fish. Sci., 65, 436-440.

Sulistiono, D., M. Yokota, S. Kitada and S. Watanabe. 1999. Age and growth of Japanese whiting Sillago japonica in Tateyama Bay. Fish. Sci., 65, 117-122.
Von Bertalanffy, L. 1938. A quantitative theory of organic growth (Inquiries on growth laws II). Human Bio., 10, 181-213.

Whitehead, P.J.P. 1985. Clupeoid fishes of the world. FAO species catalogue, 125, 1-303.

Youn, C.H. and I.S. Kim. 1998. Taxonomic revision of the family Clupeidae (Pisces: Clupeiformes) from Korea. Kor. J. Ichthyol., 10, 49-60.

Yamada, U., M. Tagawa, S. Kishida and K. Honjo. 1986. Fishes of the East China Sea and the Yellow Sea. Nihon Shinko, Nagasaki, 1-501.

(Received January 2007, Accepted March 2007) 